\title{
Community-Based Natural Resource Management in Mozambique: A Critical Review of the Concept's Applicability at Local Level
}

\author{
Pekka Virtanen* \\ University of Tampere, Finland
}

\begin{abstract}
Since the early 1990 s community-based natural resource management (CBNRM) has become a mantra of sustainable development, which has been broadly embraced by national leaders and policy-makers in Africa, as well as aid bureaucrats and technical specialists in donor countries. Its dissemination to local communities, however, has turned out to be a rather controversial process. On the basis of two case studies this article assesses the extent to which the new approach has been adopted in Mozambique, and the conditions on which it has been accepted by local communities. The results indicate that the CBNRM model cannot be considered independently of the local political context, even though this aspect has been largely neglected. Devolution of full authority to local institutions is also a crucial issue. Restrictions on the use of natural resources are acceptable to the local population, but only if they are compatible with local livelihood strategies. Copyright (C) 2004 John Wiley \& Sons, Ltd and ERP Environment.
\end{abstract}

Received 12 September 2002; revised 7 April 2003; accepted 28 July 2003

\section{Introduction}

INCE THE 1992 UNITED NATIONS CONFERENCE ON ENVIRONMENT AND DEVELOPMENT IN RIO DE Janeiro, community-based natural resource management (CBNRM) has been increasingly accepted as the 'privileged solution' to the challenge of environmental conservation in developing countries (Adams and Hulme, 200I; Wily, I999). The key message of CBNRM proclaims that if economic development and community participation are not promoted in conjunction with environmental conservation, then local populations will have no interest in protecting resources, which will not survive. This message has been repeated in scientific publications, policy documents and popular media

* Correspondence to: Pekka Virtanen, Department of Political Science and International Relations, University of Tampere, FIN-33014 Tampere, Finland.E-mail: mariola@mbnet.fi 
until it has turned into a mantra of sustainable development (see, e.g., Godwin, 200I, p. 29). It has been broadly embraced by national leaders, policy-makers, administrators and private sector operators in developing countries, as well as aid bureaucrats and technical specialists in donor countries (Adams and Hulme, 200I, pp. 9-IO). In such a process the message can lose its function of providing new information and become autocommunication, communication to oneself (Lotman, I990, pp. 20-35).

In Africa the status of CBNRM as 'the right approach' to sustainable development emerged very rapidly during the I990s, and it is only recently that debate has began to surface on its concrete merits and demerits, economic costs and benefits, and conditions for its effective implementation. While there is an extensive literature on CBNRM, most of it consists of optimistic 'success stories' told by those involved in the projects and actively promoting the concept, often without sufficient critical distance (Adams and Hulme, 200I, pp. I8-I9). This article seeks to contribute towards the development of a more comprehensive and analytical view of CBNRM, based on two case studies from Mozambique.

The success of the CBNRM approach is linked to its compatibility with the new international policy agenda emerging after the collapse of the socialist regime and the ending of the Cold War in the early I990s. The new agenda basically combined neo-classical economics with liberal democratic theory. In recognizing the importance of economic incentives and markets, and calling for a reduced role of the state, the CBNRM approach was in line with the former; in helping communities to organize themselves to manage natural resources it was believed to be strengthening civil society, and thus deepening the process of democratization (Adams and Hulme, 200I, p. I7).

While the CBNRM message has been broadly absorbed by the international and national bureaucratic and political elites, its reception by lower-level state authorities and local populations living in target areas has been more sceptical. As noted by the proponents of the 'new rhetorics', a speaker can develop his argumentation only by linking it to theses acknowledged by the audience to be valid: that is true, normal or at least probable. A message must anchor itself in the socio-cultural basis of its audience. Theses thus acceptable may be those of common sense (as conceived by the audience), of religious or political doctrine, or of scientific scholarship, among others (Perelman, I959, p. I25). In the case of CBNRM its evident success among elite groups within developing countries results from the internationally constructed socio-cultural basis shared by both promoters and audience. Rural populations in developing countries, however, even lower-level state bureaucrats, are not likely to share the same basis (Murombedzi, I999, p. 29I; Ribeiro, 200I, p. II). It should also be borne in mind that, even though political leaders may express their support for new policy initiatives, the actual policy implementation process tends to be incrementalist, and lower-level officials have considerable discretionary powers (Adams and Hulme, 200I, p. 22).

In line with neo-classical economics, the standard CBNRM message emphasizes economic incentives as the key to successful community participation (see e.g. Matakala and Mushove, 200I, p. 33). However, the prevailing economism has been criticized by some authors, who deplore the way economic rationality is used to downplay social norms, while social relations are reduced to economic instrumentalism. They remind us that even though economic benefits are important, less concrete sociocultural or tenurial interests are often at least equally important in achieving sustained community management. Rather than being consciously and rationally 'crafted', however, local institutions of collective management evolve through both conscious and unconscious acts by various stakeholders, including substantial borrowing from existing local institutions and patterns of social interaction (Cleaver, 2000, pp. 36I-366). Therefore, some researchers have emphasized the need to share jurisdiction over the resource with the communities, not simply the right to use or gain from forest products, as is typically the case. An ambivalent release of authority to the local level can reproduce local inequality and impair the motivation of the community to assume responsibility for forest management (Walker, I999, pp. 278-279; Wily, I999, pp. 49-50). 
In this article I will assess the extent to which the new policy has guided the ongoing process of legal reform by making CBNRM a viable option in Mozambique, and the conditions on which the new management approach has been accepted by local communities and developed into a sustainable process in the pilot projects studied. Mozambique was selected for the study because it presents almost ideal conditions for the implementation of internationally conceived development models such as CBNRM. According to Adams and Hulme (200I, p. I9) the following factors are crucial: (i) donor experts and domestic constituencies are attached to the model; (ii) there is political, strategic or moral pressure on the international community to act promptly; (iii) there has been little technical or socio-economic research in the field locally; (iv) the recipient country is heavily dependent on foreign aid and experts and (v) the recipient government is weak or authoritarian. As I show below, Mozambique fulfils most of these conditions.

\section{The Evolution of CBNRM in Mozambique}

Under Portuguese colonial rule nature conservation in Mozambique was based on a system of protected areas comprising national parks, game reserves, controlled hunting areas and forest reserves. Protected areas covered about Io\% of the total area (Hatton and Munguambe, I997, pp. 32-33). In principle the approach followed the then dominant 'fortress conservation' concept, which excluded people as residents in the areas, and called for the prevention of consumptive use and minimization of other forms of human impact (Adams and Hulme, 200I, p. I0). Perhaps the most common strategy used by both colonial and post-colonial forest administrations in Africa in the 2oth century was the establishment of forest reserves. Initially this approach was used to secure the state's access to prime natural forests, but it has also constituted a means to protect watersheds as well as economically and scientifically valuable tree species. Between I943 and I974 the colonial government in Mozambique established I5 forest reserves (Hatton and Munguambe, I997, p. 33; Wily, I999, p. 51).

After the independence of Mozambique in 1975 the forest reserves were practically abandoned, even though legally they still belonged to and were managed by the government (Serra, 20oI, p. 3). This defunct state was complemented by a I6-year civil war (I977-I992), which reduced effective state control over conservation areas to the two insular sites of Inhaca and Bazaruto in the Indian Ocean. With the arrival of peace after the I992 Rome Accords the international conservation community awakened to the apparently devastating situation of wildlife, decimated by the Renamo rebel army, but also by government forces, to finance their operations during the war (McGregor, I998, p. 55; Schafer and Bell, 2002, p. 4I3). As the previous conservation administration had relied largely upon Portuguese experts, Mozambique had practically no national capacity to rehabilitate its system of conservation areas. On the other hand, international NGOs such as the World Conservation Union (IUCN), the Endangered Wildlife Trust (EWT) and the Ford Foundation were quite willing to provide expertise and even some financial support, provided that a new conservation policy based on the CBNRM was adopted. All three NGOs had had experience of the new approach in Southern Africa, and operated from Zimbabwe or South Africa. With the Rio Conference nature conservation had also established a strong position in the development programmes of various multi- and bilateral donor agencies such as the World Bank and the USAID (Anstey, 200I, pp. 79-82; Singh, 200I, pp. I02-I03).

The model promoted by foreign agencies relied heavily on the experience gained from ecotourism and sports-hunting-based CBNRM programmes such as the Zimbabwean Campfire and the Zambian Admade, which were widely publicized in the international media (Anstey, 200I, pp. 8I-84; Matakala and Mushove, 200I, p. I2). Aside from some community participation in marine resource management at Bazaruto and Inhaca, the first CBNRM project in Mozambique was actually a replica of the 

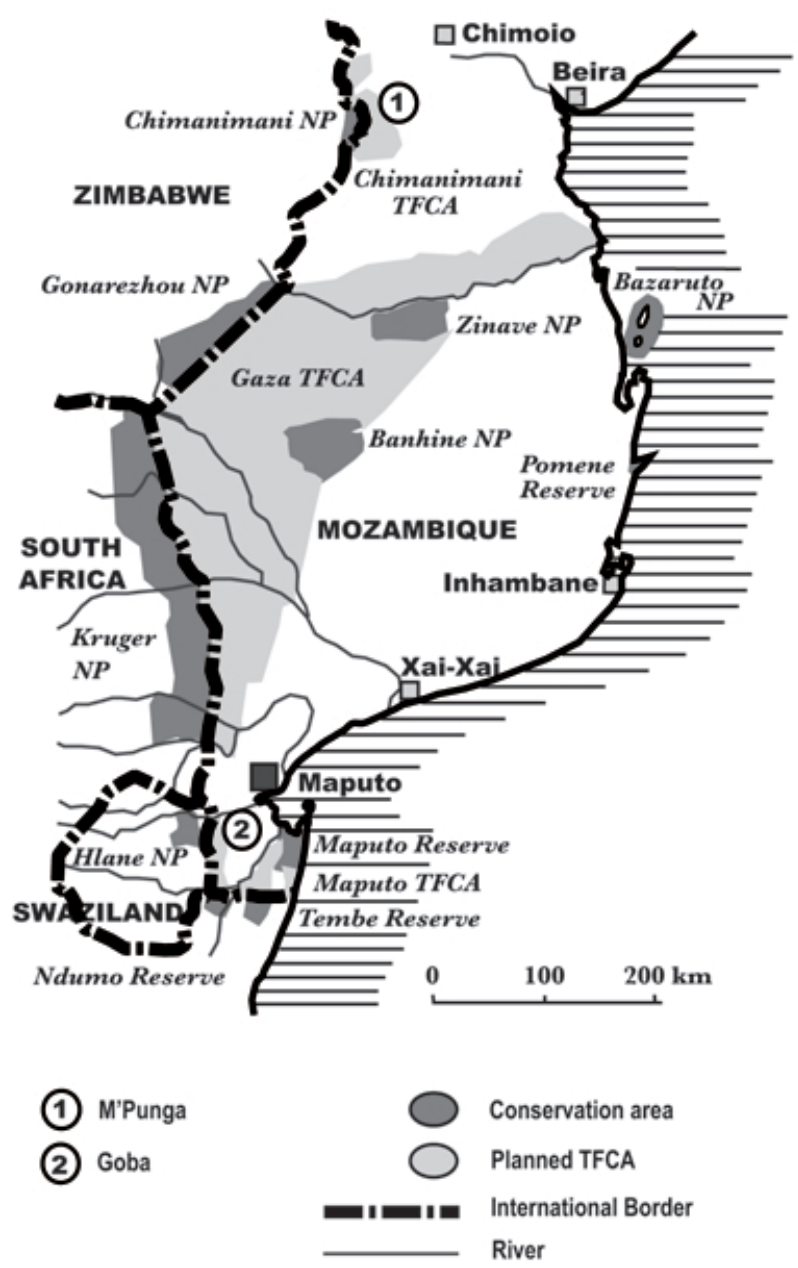

Figure 1. The planned transfrontier conservation areas in Mozambique

Campfire model called Tchuma Tchato, which was initiated in I994 in a sparsely populated and remote part of the Zambezi Valley in Tete Province (Madope, I999). It was based on the biological arguments used by Campfire, which emphasize that viable populations of Africa's most prized mobile wildlife species require large dispersal areas. Conservation must thus extend beyond protected areas into the wider landscape, where a compromise must be found between wildlife and the needs of local communities (Adams and Hulme, 200I, pp. I7-I8).

One year later the government approved a Transfrontier Conservation Areas Project (TFCA), the first major proposal for new conservation areas since independence. Like Campfire, the TFCA is an ecosystem-based and multiple land-use project. It is funded by the Global Environmental Facility (GEF) through the World Bank. It comprises three transfrontier conservation areas in the central and southern parts of the country (see Figure I). The Maputo TFCA is situated in the southern part of Maputo Province, and includes the Maputo Elephant Reserve and a proposed transit corridor, which would link the reserve with the Tembe Elephant Park and Ndumo Game Reserve in South Africa. According to some plans it would eventually be extended along the south-western border of Mozambique to reach the Hlane Royal National Park and two adjacent nature reserves in Swaziland. The Chimanimani 
TFCA in the Province of Manica is contiguous with the Chimanimani National Park in Zimbabwe, and includes the eastern escarpment and foothills of the massif of the same name. Finally the Gaza TFCA, the largest of the three, lies in the Provinces of Gaza and Inhambane in Mozambique. It borders on the Kruger National Park in South Africa and the Gonorhezhou National Park in Zimbabwe (Hatton and Munguambe, I997, pp. 32-33; Soto et al., 200I, p. I724).

Since I997 the focus of CBNRM projects in Mozambique has shifted from wildlife to forest management. They continue, however, to be externally initiated: a recent survey revealed that out of the 42 ongoing projects 37 had been initiated by the government and/or a donor agency (Matkala and Mushove, 200I, pp. I9-23). Paradoxically, policies and decisions for community participation are made by people outside the communities concerned. The government structure has historically been heavily centralized, and the system tends to empower outsiders while the local people are reduced to the status of passive beneficiaries. For example, in the case of the Maputo TFCA a study found that local communities were inadequately informed about the new initiative, and had not been integrated as partners in the management of the reserve. Similar problems have been reported from other environmental projects in the province (Soto et al., 200I, pp. I725-I73I; Walker, I999, pp. 274-276).

According to the laws in force in Mozambique up to I997, the rural population could only benefit from subsistence use of natural resources, being excluded from the marketing of these resources, which was normally carried out by outsiders such as safari operators, private hunters and commercial loggers. At the same time the revenue collected by the state through fees and taxes was very low, and the enforcement capacity of the relevant state institutions was weak (Cuco, I994, p. 49; Ribeiro, I999, pp. 90-9I). One of the key lessons learned from the problems encountered in the Campfire programme is related to this issue. As the Zimbabwean programme has not been able to devolve authority over natural resources from the central government to producer communities due to legal constraints, effective power over use and management rests at district level and with sectoral authorities. Wildlife management thus continues to be driven by external economic and policy interests rather than responding to local needs (Murombedzi, I999).

Despite a number of new laws passed between I997 and I999 dealing with natural resources, the position of local community institutions in Mozambique remains vague. The new laws provide no clear indication as to the role reserved for locally based institutions such as traditional authorities and customary law in the management of natural resources (Salamão, i999, pp. 84-87). In rural areas these have only a consultative role, while actual powers depend on the discretion of state authorities at the district and higher levels. In point of fact CBNRM seems to be operating in a legal vacuum: in more than $80 \%$ of the cases studied, community natural resource management committees and/or the community in general made most of the decisions. In only one of the 42 cases, however, does the management committee have adequate legal status (Matakala and Mushove, 200I, pp. 52-53). Another study indicates a serious communication problem between the government and rural communities; local people are frequently not even aware of their rights, and have little confidence in the government. Only one-quarter of the respondents in the Maputo TFCA knew that the government had passed a new land law, and two-thirds of those who knew thought that it was only good in principle, for they doubted the government's commitment in ensuring its equitable implementation (Soto et al., 200I, p. I730).

\section{The Case Studies}

Diffusion of the CBNRM message to rural areas is expected to take place essentially through pilot activities, where local communities are the main audience. Below I will look more closely into two pilot cases, the M'Punga project in Manica Province and the Goba project in Maputo Province (see Figure I). Aside 
from the objective of strengthening sustainable natural resource management in the target communities, the projects have broader targets with respect to replicability and the establishment of institutions. These include developing a sustainable approach for local communities to manage their natural resource base and enhance their well-being, and enabling the government to update policies, regulations and practices related to community land tenure and access to natural resources. The Goba project has been implemented since 1998 by a technical support unit for CBNRM established within the National Directorate of Forestry and Wildlife (DNFFB) under a FAO forestry project. The M'Punga project, again, is part of an action research programme implemented by CEF, the Forest Research Department of DNFFB, with support from the Ford Foundation. Implementation of project activities started in 1996 (Fisher et al., 200I, pp. 7, I4; Serra, 200I, p. 6).

The two pilot projects are both located within existing or planned TFCA areas, which cover two of the three 'biological hotspots' identified in Mozambique. These are the Maputaland centre of endemism in the extreme south of the country, and the Afromontane area in the escarpment region along the frontier with Zimbabwe in central Mozambique. The Maputaland centre of endemism has an unusually rich and interesting fauna and flora, including nearly 500 species of birds, of which 47 subspecies are endemic or near-endemic. At least I68 species/infraspecific taxa of vascular plants are also endemic or nearendemic to the area. The Afromontane habitat, to which the Chimanimani massif belongs, is also characterized by an exceptionally high diversity of habitats and species. At least 45 vascular plants growing in the area are endemic or near-endemic, as well as a number of bird species (Hatton and Munguambe, I997, pp. I3-I5). The Moribane forest in M'Punga is also one of Mozambique's few patches of rain forest (Serra, 200I, p. 6).

While both M'Punga and Goba are thus of high relevance for nature conservation and policy development, and the target communities are of approximately the same size, their juridical, socio-economic and political conditions differ considerably. The main differences concern political patronage, dependence on agricultural production and access to markets.

\section{M'Punga}

M'Punga is a traditional chieftaincy lying about $80 \mathrm{~km}$ from Chimoio, the provincial capital of Manica (Figure I). It covers an area of about $\mathrm{I} 20 \mathrm{~km}^{2}$, including the Moribane Forest Reserve established by the colonial government in I950, which extends over $53 \mathrm{~km}^{2}$. The maximum altitude of the area is $650 \mathrm{~m}$ above sea level, with an annual average rainfall of about IIoo $\mathrm{mm}$. The forests include rain forest on the tops of the mountains, forest galleries along the rivers, and mixed tree species along the slopes. M'Punga also serves as a buffer zone for the Chimanimani TFCA, and forms part of the same ecosystem. The population in M'Punga number about 1900 , of whom over $70 \%$ are originally from the area (Serra, 200I, p. 3). The Sussundenga District, to which the project area belongs, shares a border with Zimbabwe, and the two sides are historically linked by trade, kin and labour migration (Alexander, I997, p. 9). Local people on both sides speak ChiNdau, a dialect of Shona, which was also favoured by the Renamo leadership (Schafer and Bell, 2002, p. 409; Singh, 200I, pp. 60-7I).

Road access to the study area had been opened by logging companies during the colonial period, but after Mozambican independence the bridges and other infrastructure were bombarded and destroyed by Rhodesian forces, which frequently violated national borders during their military operations. This increased the population's isolation and marginalization, and it proved extremely difficult to extend the grip of the new Frelimo government over the dispersed households. The task became impossible when Renamo arrived in southern Sussundenga at the beginning of the civil war in I977, and the area became the guerrilla army's regional headquarters (Alexander, 1997, pp. 9-15; Schafer and Bell, 2002, pp. 
406-408). As a large part of the local population were hostile to the new government, only about $20 \%$ of the inhabitants of M'Punga fled the war to other areas in Mozambique or to Zimbabwe, while the remainder withdrew to the mountains and closed canopy forests under Renamo control. When the war ended in I992 some people remained in the dense forest and started to fell timber to clear land for farming. By I997 some 60\% of households were still living within the boundaries of the reserve (Serra, 200I, p. 3).

The majority of the population continues to support the opposition, and in the I994 parliamentary elections Renamo obtained nearly $60 \%$ of the valid votes in the Sussundenga District, while Frelimo had to do with less than 30\% (de Brito, I995, p. 497). When the CEF team first approached the population in 1995 the reception was openly hostile, and the situation deteriorated further as they tried to reestablish some restrictions on the use of natural resources inside the reserve. There was even some suspicion that the government sought to expropriate land and give it to white farmers, as was the case elsewhere in the province. Initially the problem focused on Chief M'Punga, who refused at first even to meet the government team. Subsequently collaboration with him improved, as he perceived the project's value as a source of additional resources for reinforcing his own position. It soon became evident, however, that the chief's legitimacy was questioned by some members of the community on the basis of traditional rules of succession. He had been nominated under the influence of Renamo and now tried to balance between the two political forces. Gradually he became increasingly dependent on the project, and indirectly on the government, as a source of power and legitimacy (Schafer and Bell, 2002, pp. 407-4II; Serra, 200I, pp. 7-I2).

As relations with the chief were difficult, the government representatives suggested the creation of a community committee, with an equal number of democratically elected men and women representing the whole population. This was rejected by the community, and finally five young men, one from each village, were nominated by the respective headmen. Having no independent legitimacy, the committee became very passive, playing mostly the role of a messenger between the chief, his headmen and the project staff. It has no legal status, and the members remain subordinate to the respective headmen and the project staff. On the other hand, traditional rules concerning the use and management of natural resources are no longer obeyed either (Serra, 200I, pp. I2, I4).

Another initiative by the government team was the creation of income-generating groups to direct people's interests away from ecologically precarious activities. The alternative activities proposed included beekeeping, fish farming and horticulture, as well as improved agricultural practices to reduce deforestation and protect the soils. Again the arguments presented by the project staff were not compatible with the expectations of the audience. The beekeeping group was rejected because it was proposed as a women's group, while in M'Punga beekeeping was considered a male activity. Even though a men's beekeeping group was subsequently created along with some other groups, their membership consisted mostly of newcomers to the area, those returnees who took refuge in the government controlled areas during the civil war, and the subjects of one headman who was deeply involved in a local power struggle. In other words, their status in the community was marginal (Serra, 200I, pp. 9-IO, I5).

The new economic activities were not competitive with the existing alternatives, which the project sought to restrict. The main source of livelihood in M'Punga is agriculture, based on the cultivation of maize, sorghum, bananas and yam. The last two are grown as cash crops along river valleys, and they represent the most important source of income for the majority of households. Their cultivation has increased rapidly since I995, this leading to the clearing of ecologically important catchment areas. Wildlife also traditionally provides an important source of protein, and has been a major source of income for some households. Apart from crafts and medicinal plants it is one of the few forest products that have ready markets (Serra, 200I, pp. I3-I4). On the other hand, the relatively insignificant material benefits provided by the project were largely annulled by the damage caused by elephants, which 
the project aspired to protect. Although in 1997-1998 the increasing elephant population destroyed banana and maize crop fields, the project staff failed to solve the problem (Schafer and Bell, 2002, pp. 4I3-4I5).

Seven years after the first contact a climate of distrust continues to reign in M'Punga between the community and the government staff, and even within the community. The project has failed to base its argumentation on premises that are acceptable to the majority of community members, and the tense relationship has led to a number of confrontations in public meetings (interviews, M'Punga, 5 April I999; cf. Singh, 200I, pp. I29-I33). Aside from party politics and lack of material benefits, the feeling of distrust has been strengthened by a failure of the government and some NGOs linked to the project to keep their promises concerning such concrete issues as education services and markets for the alternative products promoted by the project (Serra, 200I, pp. I5-16).

\section{Goba}

Goba is a village located in the Namaacha District in Maputo Province, some $75 \mathrm{~km}$ south-west of Maputo, the capital of Mozambique (Figure I). It lies at the edge of the Lebombo mountains, which separate the south of Mozambique from Swaziland and South Africa. The heights reach $800 \mathrm{~m}$ above sea level, and the area has an annual rainfall of about $700 \mathrm{~mm}$. The land falls within the traditional chieftaincy of Mazia, which extends through family bonds even to neighbouring Swaziland (Mansur and Nhantumbo, I999, p. 4). The local population has close connections across the border, including kin and cultural affiliation with the Swazi and Zulu ethnicities. Many inhabitants of Namaacha were already absorbed in the foreign labour markets before the war (McGregor, I998, pp. 45-46). The pilot area for the CBNRM project corresponds to the micro-watershed of Maxavachane, an affluent of the Umbeluzi river, and covers an area of about $96 \mathrm{~km}^{2}$. The population is about $\mathrm{I3} 300$. The project was initiated by the forestry authorities to combat the uncontrolled charcoal production which was degrading the area, and also because Goba serves as an important catchment area for the Umbeluzi river, which is Maputo's only source of drinkable water (Gilmour, 2000, p. 8).

With the rapid growth of the capital after independence, and further due to increasing numbers of war displaced in the late I970s, the demand for consumer goods such as wood fuels rose sharply. In Namaacha, charcoal production for the Maputo market became a major source of cash income. Initially the production remained under local control, as access to trees was regulated by local community institutions, and transport was organized through local shop-keepers and truck owners. In I984, however, the situation changed drastically as Renamo moved into the area, and most of the local population fled either to Swaziland and South Africa, or to Maputo. Due to the government's counter-tactics, which included concentration of the rural population in villages and bombardment of areas close to suspected guerrilla bases, Renamo never managed to organize the remaining population for effective production. Instead it facilitated their exodus to neighbouring countries, and subsequently relied on the informal markets and refugee communities established there (McGregor, I998, pp. 46-51).

Gradually effective government control in Namaacha was restricted to administrative posts and other strategic locations such as traffic junctions. Old charcoal supply networks were also disrupted, as most of the burners and transporters fled the area. This situation privileged a new group of formerly marginalized rural migrants, largely unemployed young men from the provinces of Gaza and Inhambane, who, along with soldiers and militias, took over the trade. Geographically the activity was restricted to areas in the vicinity of military posts, for example the railway station in Goba. Due to the precarious nature of the situation and the lack of local control mechanisms, production was totally unsustainable. 
The burners clear-felled areas to which they had relatively safe access, and then moved over to deforest new areas (McGregor, I998, pp. 55-58).

The settlement of the immigrant charcoal burners and their exploitative extraction of resources led to individual conflicts as pre-war residents started to return after the war. In the end the immigrant group nonetheless retained a relatively strong position: for example in the socio-culturally heterogeneous population of Goba over half of the present inhabitants are from the Gaza and Inhambane provinces, while only $20 \%$ are from Maputo. Over $80 \%$ of families are involved in the charcoal business, which remains the main cash activity (Filimão, I998, pp. 2-3). Politically the population of Namaacha supports Frelimo. In the I994 parliamentary elections over $80 \%$ of the valid votes were cast for the ruling party, while Renamo received only six per cent (de Brito, I995, p. 497). The support is, however, mixed with distrust, as indicated by the lack of confidence in the government's declared decentralization policy (Soto et al., 200I, p. I730).

Even though the CBNRM project only commenced activities in I998, a pilot project had been under preparation since I995, but lacked funding until the FAO project was finally approved in I997. Preparatory studies indicated that the existing institutions did not provide a sufficiently strong basis for the CBNRM approach. Thus, while both traditional and local government authorities were involved in and favourable to the process from the onset, it was considered necessary to create a local natural resource management committee. The committee members were selected by the community in public meetings. The project sought to keep a low profile, even though it did recommend that a gender balance and equity principles should be observed, and that people already occupying political posts should be avoided. Eventually a committee of 30 , composed of 15 men and I5 women representing the three villages, was created (Mansur and Nhantumbo, I999, pp. 5-7). The project has actively supported the committee's endeavour to obtain formal tenure right and authority to decide on the management of natural resources. In 200I the association was legally recognized by the government, which makes it the only CBNRM project in Mozambique where the community has full de jure powers and authority (Matakala and Mushove, 200I, p. 24).

Based on a participatory process including an inventory of natural resources and zoning exercises, the community approved a management plan which regulates the use of natural resources, and sets quotas on timber extraction and charcoal burning, as well as other activities such as hunting. The regulations also restrict the rights of use to resident members of the local community, and set a license system to control the overall volume of extraction. Detailed guidelines indicate the type of use for each zone, and define the quantity, species, period of use and extraction practices to be followed. To some extent the plan is based on traditional rules. As a result of the strict limitations laid down in the plan, a number of households left Goba. Overall, however, the rules have been accepted and the process has brought the use of natural resources under control despite a continuing strong demand for charcoal, which remains the main source of cash income (Fisher et al., 200I, pp. I2-27).

Aside from training in management skills, the project has supported the creation of interest groups for carpentry, tinsmithing, beekeeping, guinea-fowl raising, dressmaking, a tree-nursery and even a theatre group. There are also plans for developing ecotourism facilities in a scenic area close to the Swaziland border (interviews, Goba, 2I November 200I). However, the interest group approach has been criticized for not making any direct contribution to natural resource management, and for lacking sustainability as the groups provide only limited benefits to a small number of people. This is linked to the project's approach to community organization, which works by attracting interested people rather than building an institution that represents all the diverse stakeholders. The approach has led to a situation where the committee has become an elite faction, which does not necessarily enjoy the confidence of the wider community. The problem of divergent interests has manifested itself for example in a group of I5 new families who recently constructed houses and opened fields outside the defined areas, 
supposedly with the approval of some local authorities. The community wardens have also faced difficulties in apprehending poachers and combating bush fires, caused mainly by locals (Fisher et al., 200I, pp. IO-I7; Gilmour, 2000, p. 9). Thus, even though an influential part of the population of Goba has absorbed the CBNRM message, the project has not managed to address the concerns of the whole community. The community activists involved in the project also acknowledge this shortcoming (interviews, Goba, 2I November 200I).

\section{Conclusions}

When a text or a strategic plan is read in a self-oriented manner, it acts as a mantra: it enhances the audience. Instead of a plan for action, the message becomes a code, which transports the reader's mind to a mythical plane. The information included in the message acquires new content, a make-believe content that indicates what one should become, what one should look like (Broms and Gahmberg, I983, pp. 482-490). In Mozambique the popular mantra of CBNRM has been adopted as the official conservation strategy by the government. Its dissemination to local communities, however, has turned out to be a rather controversial process.

Since the transition to multi-party democracy in I994, Mozambique's parliament has passed a number of new statutes, which in principle make CBNRM legally possible. However, due to disagreements within the ruling party the new laws remain vague, and decentralization of authority over natural resources to local communities depends on the discretion of state authorities. So far the respective authorities at national and provincial levels have been reluctant to devolve the powers downwards, and by 200 I only one community (Goba) had obtained full authority over their resource base. At present CBNRM seems to be operating in a legal vacuum, as local communities are given various responsibilities and even de facto powers without corresponding de jure authority. The findings of this study concur with those of Matakala and Mushove (200I, pp. 38-39), who state that the CBNRM approach in Mozambique has been paternalist and overly rhetorical. Without adequate legal status local communities can easily become powerless facades to legitimize decisions made elsewhere.

The problem is not unique to Mozambique. Many of the new 'democratic' governments elected in Africa since the early I990s have largely failed to challenge established elite interests, or to create and maintain effective institutions to ensure rule enforcement while improving government accountability and local participation. Even though the basic structure of colonial conservation policy maintained in most African countries after independence has been replaced by the CBNRM approach, the old topdown command mentality has often survived at the implementary level - albeit with weak enforcement capacity. The schizophrenic government policies have led to an embittered stalemate between state authorities, who are unable to fully enforce the new environmental policies, and rural populations unable to fully escape central demands and controls (Walker, I999, pp. 260-265).

The two cases studied indicate that the CBNRM model cannot be considered independently of the local political context. In M'Punga the population were decidedly hostile towards the government and its programmes, interpreting them - more or less correctly - as an attempt to extend government control to the political opposition's stronghold (Schafer and Bell, 2002, p. 403). Consequently they did not share the political premises of the project staff who tried to spread the CBNRM message. Even though the local population were also somewhat sceptical towards the government in Goba, the district is generally favourable towards the ruling party, and the project idea was considered more favourably than in M'Punga. The project's policy of avoiding direct party linkages was probably also expedient. The way the audience appraises the sender's political intentions is evidently a crucial factor in argumentation, but has been largely neglected in the CBNRM debate. 
In both areas existing institutions turned out to be relatively inefficient in terms of the CBNRM objectives. However, while new institutions were in both cases initiated under project pressure, the outcomes differ markedly. In Goba the committee succeeded in creating a relatively robust management regime by bringing the exploitation of trees for charcoal burning under local control. Support from the project in obtaining full legal authority over local natural resources was crucial for success, even though the approach has also led to the exodus of some households and marginalization of some stakeholder groups within the community. In M'Punga the committee was accepted only reluctantly, and it lacks both authority and initiative. Those who participate actively in its activities tend to come from socio-politically marginalized sections of the community, and are not likely to be effective opinion-leaders. Interestingly, the success has been better in the heterogeneous community of Goba than in the socio-culturally more homogeneous M'Punga. This is at odds with the popular literature on institutions, which asserts that sociocultural homogeneity is an advantage in CBNRM projects (cf. Cleaver, 2000, pp. 369-370). At least in the case of 'crafted' institutions, heterogeneity is not always a disruptive factor. However, the viability of the new institutions in Goba is yet to be seen.

While economic factors are no doubt important, this generalized observation needs to be contextualized. In a country like Mozambique, where almost 70\% of the population live below the poverty line, and over $80 \%$ of the poor are located in rural areas, poverty alleviation is the first priority in rural development. Nevertheless, while local inhabitants seldom consider nature conservation a priority issue, they do value various environmental services and are often willing to give up or restrict the use of some resources to maintain them. This view is corroborated by the case of Goba, where the majority of the population were willing to impose strict rules on the use of key natural resources in order to secure the sustainability of the tree resources needed to continue the lucrative charcoal business. In M'Punga the situation was quite different, as the project was not able to introduce any economically viable alternatives to the prevailing agricultural activities, which were considered destructive. The attempt to convince the local, traditionally agrarian population to refrain from increasing cultivation in the fertile gallery forests, which are the most suitable areas for growing cash crops, had few chances of success. Refusal on the grounds of nature conservation to curtail the elephant population, which was causing damage to agricultural production, hardly strengthened the project's cause. Such incidents serve as a constant reminder of the problems of reconciling local subsistence needs with nature conservation.

\section{Acknowledgement}

The author acknowledges the financial support received from the Academy of Finland through the Clima-X project.

\section{References}

Adams W, Hulme D. 200I. Conservation and community: changing narratives, policies and practices in African conservation. In African Wildlife and Livelihoods: the Promise and Performance of Community Conservation, Hulme D, Murphree M (eds). Currey: Oxford; 9-23.

Alexander J. 1997. The local state in post-war Mozambique: political practice and ideas about authority. Africa 67: I-26.

Anstey S. 200I. Necessarily vague: the political economy of community conservation in Mozambique. In African Wildlife and Livelihoods: the Promise and Performance of Community Conservation, Hulme D, Murphree M (eds). Currey: Oxford; 74-87.

Broms H, Gahmberg H. I983. Communication to self in organizations and cultures. Administrative Science Quarterly 28: $482-495$.

Cleaver F. 2000. Moral ecology, rationality, institutions and the management of common property resources. Development and Change 3r: $36 \mathrm{I}-383$.

Cuco A. I994. The impact of structural adjustment on forest industry in Mozambique. Unasylva 45(I79): 45-50. 
de Brito L. I995. O comportamento eleitoral nas primeiras eleições multipartidárias em Moçambique. In Eleições, Democracia e Desenvolvimento, Mazula B (ed.). Maputo; 473-499.

Filimão E. I998. O Significado do Carvão nas Estratégias de Sobrevivéncia e de Rendimento: o Caso de Goba. Paper presented at the First National Conference on Natural Resource Management, I998.

Fisher R, Gêmo H, Zambon P. 2oor. Support for Community Forestry and Wildlife Management: Final Project Evaluation Report, FAO Project GCP/MOZ/056/NET. Maputo.

Gilmour D. 2000. Strategies, Methodologies and Gender Approaches for CBNRM Development in Mozambique, consultant's report, FAO Project GCP/MOZ/056/NET. Maputo.

Godwin P. 200I. Uniting Africa's wildlife reserves. National Gegraphic September: 6-29.

Hatton J, Munguambe F (eds). I997. First National Report on the Conservation of Biological Diversity in Mozambique. Ministry for the Coordination of Environmental Affairs: Maputo.

Lotman Y. I990. Universe of the Mind: a Semiotic Theory of Culture. Tauris: London.

Madope A. I999. Community participation in wildlife management. In Sustainable Development in Mozambique, Ferraz B, Munslow B (eds). Currey: Oxford; 2I7-222.

Mansur E, Nhantumbo I. I999. The Experience of the Project Mozambique/FAO/Netherlands in Pilot Areas of Community Based Forests and Wildlife Management in Maputo and Nampula Provinces. Paper presented at the IASCP Conference on Common Property in Mozambique, Zongone, I999.

Matakala P, Mushove P. 200I. Arranjos Institucionais para o Maneio Comunitário dos Recursos Naturais (MCRN): Perfis e Análise de 42 Iniciativas de MCRN em Moçambique. FAO-DNFFB: Maputo.

McGregor J. I998. Violence and social change in a border economy: war in the Maputo hinterland, I984-I992. Journal of Southern African Studies 24: 37-60.

Murombedzi J. I999. Devolution and stewardship in Zimbabwe's CAMPFIRE programme. Journal of International Development II: $287-293$.

Perelman Ch. I959. Les cadres sociaux de l'argumentation. Cahiers Internationaux de Sociologie 26: I23-I35.

Ribeiro A. I999. Institutional development for community-based resource management research. In Sustainable Development in Mozambique, Ferraz B, Munslow B (eds). Currey: Oxford; 88-96.

Ribeiro A. 200I. Natural Resource Management Policy in Mozambique: an Overview, Marena Research Project Working Paper 7. University of Liverpool: Liverpool.

Salamão A. I999. Institutional co-ordination and harmonizing formal and customary law in the management of natural resources. In Sustainable Development in Mozambique, Ferraz B, Munslow B (eds). Currey: Oxford; 83-87.

Schafer J, Bell R. 2002. The state and community-based natural resources management: the case of the Moribane Forest Reserve, Mozambique. Journal of Southern African Studies 28: 40I-420.

Serra A. 200I. Legitimacy of Local Institutions for Natural Resource Management: the Case of M'Punga, Marena Research Project Working Paper 3. University of Sussex: Brighton.

Singh J. 200I. State-Making and Community-Based Natural Resource Management: Cases of the Vhimba CAMPFIRE Project (Zimbabwe) and the Chimanimani Transfrontier Conservation Area (Mozambique), Ph.D. Dissertation. University of Washington, College of Forest Resources: Seattle, WA.

Soto B, Munthali S, Breen C. 200I. Perceptions of the forestry and wildlife policy by the communities living in the Maputo Elephant Reserve, Mozambique. Biodiversity and Conservation 10: 1723-1738.

Walker P. I999. Democracy and environment: congruencies and contradictions in southern Africa. Political Geography I8(3): $257-284$.

Wily L. I999. Moving forward in African community forestry: trading power, not use rights. Society and Natural Resources I2: 49-6I.

\section{Biography}

Pekka Virtanen is a Research Fellow at the Department of Political Science and International Relations, FIN-330I4 University of Tampere, Finland.

E-mail:mariola@mbnet.fi 